\title{
Electrokinetic and Flotation Investigations of Surface Properties Modification of Magnesite and Serpentinite Using Biosurfactants and Surfactants
}

\author{
Agnieszka Didyk-Mucha ${ }^{1}$, Izabela Polowczyk ${ }^{1}$, Zygmunt Sadowski ${ }^{1}$ and Jan Kudelko ${ }^{2}$ \\ 1. Chemical Engineering Department, Wroclaw University of Technology, Wroclaw 50-370, Poland \\ 2. Geoengineering, Mining and Geology Department, Wroclaw University of Technology, Wroclaw 50-370, Poland
}

\begin{abstract}
This paper presents some results of zeta potential measurements performed into biosurfactant adsorption onto magnesite and serpentinite surface. Zeta potential and isoelectric point measurement of magnesite and serpentinite particles before and after interaction with biosurfactant broth solution and activator (nickel(II) ion solution) were carried out. The zeta potential results show that presence of biosurfactants changes both magnesite and serpentinite surface potential by physical adsorption which increases the hydrophobicity of mineral particles. Measurements of particles zeta potential in the presence of biosurfactant broth are relevant to the minerals flotation. Hallimod flotation response of magnesite and serpentinite as a function of collector concentration was investigated. Bioflotation test results show that at the presence of broth, the flotation separation of magnesite from serpentinite is possible.
\end{abstract}

Kay wards: Zeta potential, adsorption, bioflotation, biosurfactant, activation, serpentinite, magnesite.

\section{Introduction}

The phenomenon of solid surface biomodification is still an open issue despite some attempts to explain it. According to Rao [1], biomodification is a complex action of microorganisms where the metabolic products are adsorbed on the mineral surface. The biomodification of mineral surface can be realized in three ways. The first way is attachment of bacteria cells to the solid surface. The oxidation reaction realized by special strains of bacteria at the metal sulfides is the second way. The adsorption of biosurfactants and biopolymers on the surface makes the third way of biomodification.

The adhesion of bacterial cells to the mineral surface changes the flotation behavior of the minerals. The effect of Bacillus subtilis and Mycobacterium phlei on dolomite and apatite was investigated [2].

Mineral separation by using microorganism during

Corresponding author: Zygmunt Sadowski, professor, research fields: colloids and surface chemistry. E-mail: zygmunt.sadowski@pwr.edu.pl. the flotation process is called "bioflotation" [3]. The application of chemolithothrophic bacteria such as Acidithiobacillus ferrooxidans, Acidithiobacillus thiooxidans, and Leptospirillum ferrooxidans [4] is based on the biooxidation of sulfate minerals. The depression of pyrite is due to the modification of the free surface energy of pyrite [5]. It is attributable to bacteria adhesion and bio-oxidation. The adhesion of $L$. ferrooxidans cells on the pyrite surface caused flocculation at all $\mathrm{pH}$ values. The biopolymers produced by bacteria are responsible for bridging the mineral particles and caused flocculation [6]. EBP (extracellular bacterial proteins) isolated from Paenibacillus polymyxa were used for selective separation of both pyrite and chalcopyrite from quartz, sphalerite and galena [7]. Flocculation experiments showed that in the presence of proteins (EBP), pyrite and chalcopyrite showed highest settling rate [8].

Interaction of hydrophobic bacteria cells (Rhodococcus opacus) with the mineral surface was investigated in a hematite-quartz flotation system [9]. 
Rhodococcus opacus is gram positive bacteria. The cell wall of $R$. opacus contains some polysaccharides which interacted with the mineral surface. The interaction energy between bacteria and the mineral surface was calculated using the classical DLVO theory with the X-DLVO [10].

Separation of quartz from hematite was done with the use of sulfate reducing bacteria like Desulfovibrio desulfuricans. The interaction of these bacteria with minerals caused to quartz render more hydrophobic while hematite to become more hydrophilic [10].

Biosurfactants are amphiphilic compounds containing both hydrophophilic and hydrophilic parts and are produced by a different family of living microorganisms such as bacteria, yeasts, and fungi. Biosurfactants display specific properties such as: emulsification, frothering, dispersion and surface activation reagents [11]. Biosurfactants have widely application in different industrial branches including pharmaceutics, cosmetics, agriculture, and MEOR (microbial enhanced oil recovery) [12]. Applications of biosurfactants in environment industries are focused on the remediation of heavy metal contaminated in soil and water. It was presented that the introduction of rhamnolipids enhanced the removal of arsenic and metals $(\mathrm{Cu}, \mathrm{Pb}$ and $\mathrm{Zn})$ from mine tailings [13].

The carbonation processes are proposed for $\mathrm{CO}_{2}$ storage and it is a way to the reduction of atmospheric emission of $\mathrm{CO}_{2}$ [17-19]. Serpentinite ore is mined simultaneously with other industrial minerals such as magnesite, quartz, talc, soapstone and chromium. After the magnesium separation, the ore is stored as a tailing. Initial weathering of the serpentinite tailings is accompanied by the solution with $\mathrm{Ni}(\mathrm{II})$ ions. Also, $\mathrm{SiO}_{2}$ is mobilized during weathering [20]. For this reason, both serpentinite and quartz are activated by $\mathrm{Ni}(\mathrm{II})$ ions.

The present study was aimed at finding suitable conditions for serpentinite separation from magnesite mine tailings. The role of $\mathrm{Ni}(\mathrm{II})$ ions and biosurfactants was described by the surface properties of serpentinite and magnesite investigation [20, 21].

\section{Materials and Methods}

\subsection{Biosurfactant Synthesis}

The biosurfactant was produced by pure culture of Sterptomyces $s p$. Microorganisms were grown in the mineral salt medium [PPMP] containing $25 \mathrm{mM}$ sucrose as carbon source and $10 \mathrm{mM}$ glycerol as a biosynthesis precursor. The surface tensions of the culture broth were determined at $25{ }^{\circ} \mathrm{C}$ with a ring tensiometer Krüss $12 \mathrm{~T}$ (Kruss Optische-Mechansche Werkstatten, Hamburg, Germany) as a qualitative indicator of biosurfactant production. The minimum surface tension value reached $29.7 \mathrm{mNm}-1$. The culture growth was determined as optical density changes of fermentation broth at wavelength $550 \mathrm{~nm}\left(\mathrm{OD}_{550}\right)$ using a spectrophotometer. The cultures from the end of exponential growth phase were centrifuged (3500 rpm for $25 \mathrm{~min}$ ) and the cell-free culture broth was used as the feed for flotation experiments.

\subsection{Mineral Samples}

The research was carried out using serpentinite $\left(\mathrm{Mg}_{3}\left(\mathrm{Si}_{2} \mathrm{O}_{5}\right) \mathrm{OH}_{4}\right)$ and magnesite $\left(\mathrm{MgCO}_{3}\right)$ obtained from magnesite mine Grochow (Lower Silesia, Poland). The particle size distribution of the mineral particle was determined using a Malvern Mastersizer 2000. The particle size analysis shows that mean diameters for magnesite and serpentinite were $216.1 \mu \mathrm{m}$ and $217.5 \mu \mathrm{m}$, respectively. The specific surface area of the samples was measured using a FlowSorb II 2300, according to the BET method. The BET surface area was found to be $7.6 \mathrm{~g} \mathrm{~m}^{-2}$ for magnesite and $6.6 \mathrm{~g} \mathrm{~m}^{-2}$ for serpentinite. Moreover, the XRD (X-ray diffraction analysis) (Table 1) and chemical analysis XRF (X-ray fluorescence spectroscopy) (Table 2) were performed to obtain full characteristics of mineral samples.

\subsection{Adsorption Experiments}

The initial nickel solution was prepared by dissolving nickel(II) chloride hexahydrate (POCh) in 
Table 1 The XRD pattern of magnesite and serpentinite.

\begin{tabular}{lllllll}
\hline & $\begin{array}{l}\text { magnesite } \\
(\%)\end{array}$ & $\begin{array}{l}\text { quartz } \\
(\%)\end{array}$ & $\begin{array}{l}\text { serpentine (\%) } \\
\text { (antigorite, lizardite) }\end{array}$ & $\begin{array}{l}\text { Talc } \\
(\%)\end{array}$ & $\begin{array}{l}\text { clinochlore } \\
(\%)\end{array}$ & $\begin{array}{l}\text { actinolite } \\
(\%)\end{array}$ \\
\hline magnesite & 71 & 5 & 15 & 3 & 3 & $<2$ \\
serpentinite & 2 & 3 & 70 & 10 & 5 & 8 \\
\hline
\end{tabular}

Table 2 The results of the chemical analysis (XRF) of magnesite and serpentinite.

\begin{tabular}{lllllll}
\hline & $\mathrm{SiO}_{2}(\%)$ & $\mathrm{Al}_{2} \mathrm{O}_{3}(\%)$ & $\mathrm{Fe}_{2} \mathrm{O}_{3}(\%)$ & $\mathrm{MgO}+\mathrm{CaO}(\%)$ & $\mathrm{Na}_{2} \mathrm{O}+\mathrm{K}_{2} \mathrm{O}(\%)$ & $\mathrm{LOI}(\%)$ \\
\hline magnesite & 7.18 & 0.15 & 2.89 & 43.41 & 0.16 & 46.20 \\
serpentinite & 40.40 & 1.15 & 8.49 & 36.65 & 0.19 & 12.88 \\
\hline
\end{tabular}

distilled water. Working solutions were made by diluting different volumes of initial solution to achieve the suitable nickel ion concentration: $0.05 \mathrm{M}, 0.25 \mathrm{M}$, $0.01 \mathrm{M}, 5.0 \mathrm{mM}, 2.5 \mathrm{mM}, 0.5 \mathrm{mM}, 0.25 \mathrm{mM}, 0.1 \mathrm{mM}$, $0.05 \mathrm{mM}, 0.01 \mathrm{mM}$.

In the adsorption experiments, $1 \mathrm{~g}$ of adsorbent (magnesite or serpentinite) was placed in a flask containing $100 \mathrm{ml}$ of nickel ion solution with the suitable concentration. The flask was incubated in a rotary shaker (50 rpm) at the temperature of $25{ }^{\circ} \mathrm{C}$. When the equilibrium concentration of nickel ions was reached (after $24 \mathrm{~h}$ ), the liquids were filtered and nickel ion concentration was measured using ICP (inductively coupled plasma) spectrometry. The amount of adsorbed metal was calculated.

\subsection{Zeta Potential Measurements.}

The zeta potential values of magnesite and serpentinite were measured using a Malvern ZetaMaster. The mineral samples $(<40 \mu \mathrm{m})$ were dispersed in a $1 \mathrm{mM} \mathrm{NaCl}$ solution and the $\mathrm{pH}$ was adjusted using diluted solutions of $\mathrm{HCl}$ and $\mathrm{NaOH}$. All experiments were conducted with the $\mathrm{pH}$ progressively changed from $\mathrm{pH} 10$ to 1.5 . The zeta potential of magnesite and serpentinite particles was measured in the presence and in the absence of modifier (biosurfactants solution) and activator (nickel ions).

\subsection{Microflotation Studies}

The flotation experiments were conducted using the glass Hallimond tube (height of $43 \mathrm{~cm}$; diameter of $3.8 \mathrm{~cm}$; total volume of column was about $500 \mathrm{~cm}$ ). Pure nitrogen at a flow rate of $50 \mathrm{ml} / \mathrm{min}$ for 30 min was used for flotation. For flotation tests, $1 \mathrm{~g}$ of mineral samples was added to $0.12 \mathrm{dm}^{-3}$ total volume suspensions. The suspension containing biosurfactants or anionic surfactant sodium dodecyl sulphate (SDS was purchased from POCh-POLAND) was transferred to the microflotation tube and floated. Before flotation, mineral samples were activated with a variable concentration of hexahydrate nickel chloride solution (0.5 mM, $1.0 \mathrm{mM}, 3.0 \mathrm{mM}, 5.0 \mathrm{mM}, 0.05 \mathrm{M}$, respectively) for $1 \mathrm{~h}$. The biosurfactants and SDS were conditioned with activated mineral for $2 \mathrm{~h}$. The settled and floated fractions were separated, dried and weighed. The obtained results in the concentrate were expressed as flotation recovery. Flotation recovery was calculated as the ratio of floated to unfloated minerals.

\section{Results and Discussion}

A knowledge of the surface potentials on the mineral-solution interface is important to establish the possibility of separation of serpentinite and magnesite. The values of zeta potential of serpentinite were presented as a function of $\mathrm{pH}$ for both serpentinite and active serpentinite in Fig. 1. As showed in Fig. 1, the zeta potential of serpentinite changed with increasing of $\mathrm{pH}$ of water suspension. The isoelectric point was observed to be at approximately $\mathrm{pH}=4.5$. It was also observed that the interaction of nickel ions caused an increase of positive value of zeta potential of serpentinite particles. This may be due to the selective adsorption of nickel ions on the serpentinite particle surface. The positive value of zeta potential of 
activated serpentinite was correlated with the concentration of nickel ions in the solution. An increase of concentration of nickel ions caused an increase of positive values of zeta potential of serpentinite samples (Fig. 1).

The zeta potentials of magnesite particles before and after interaction with nickel ions solution were depicted in Fig. 2. The magnesite surface showed negative values of zeta potential in the investigated pH-range. In contrast to pure magnesite, magnesite activated by $\mathrm{Ni}(\mathrm{II})$ ions showed positive values. Only at the low concentration of nickel ions $(1.0 \mathrm{mM})$ two isoelectric points were observed $\left(\mathrm{pH}_{\mathrm{iep}}(\mathrm{I})=6\right.$ and $\mathrm{pH}_{\text {iep }}(\mathrm{II})=8$ ).

The effect of nickel(II) ions concentration on the zeta potential of both minerals was presented in $\mathrm{pH}=7$ (Fig. 3). Upon ions adsorption, the mineral surface becomes increasingly covered with nickel ions and zeta potential versus ion concentration curves become less negative for serpentinite and positive for magnesite.

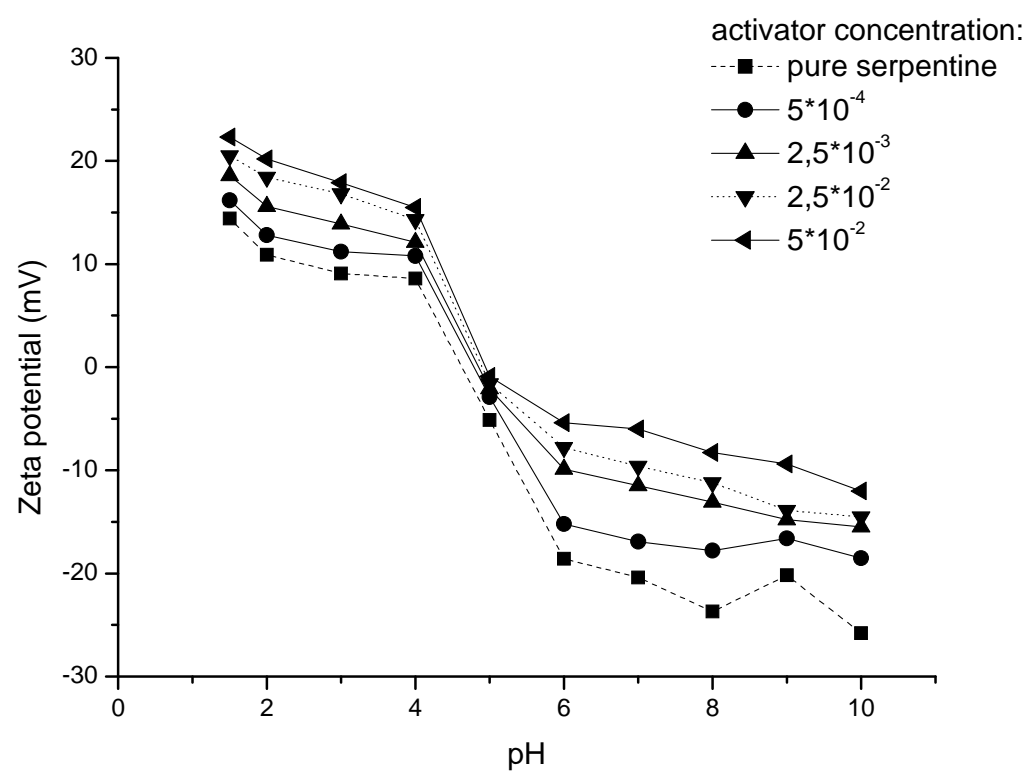

Fig. 1 Zeta potential changes of activated serpentine surface as a function of $\mathrm{pH}$ and nickel ion concentration.

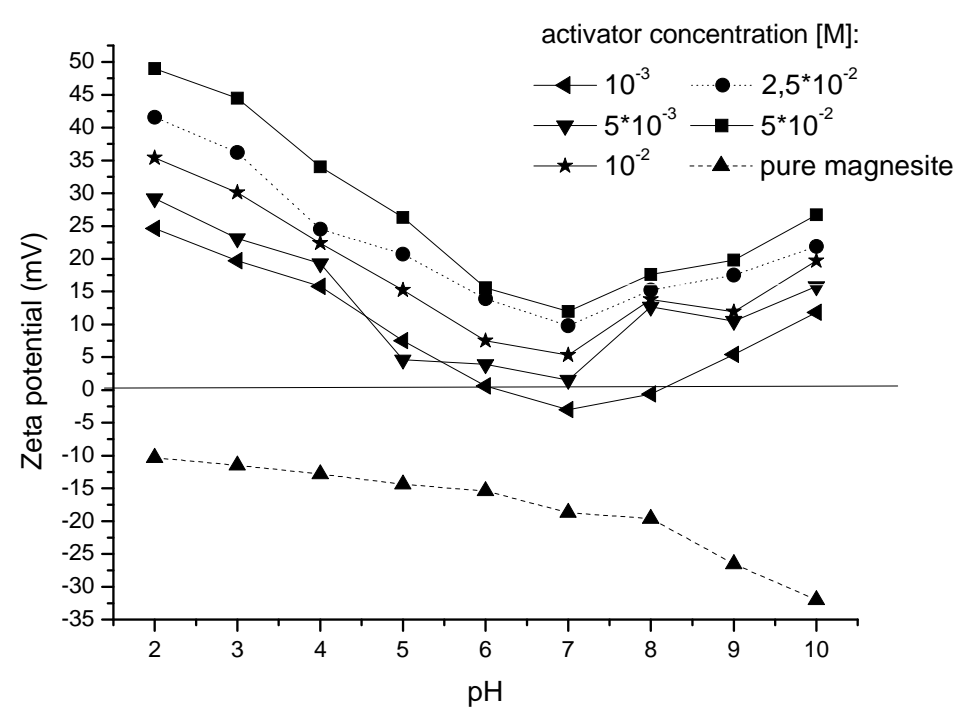

Fig. 2 Zeta potential changes of activated magnesite surface as a function of $\mathrm{pH}$ and nickel ion concentration. 


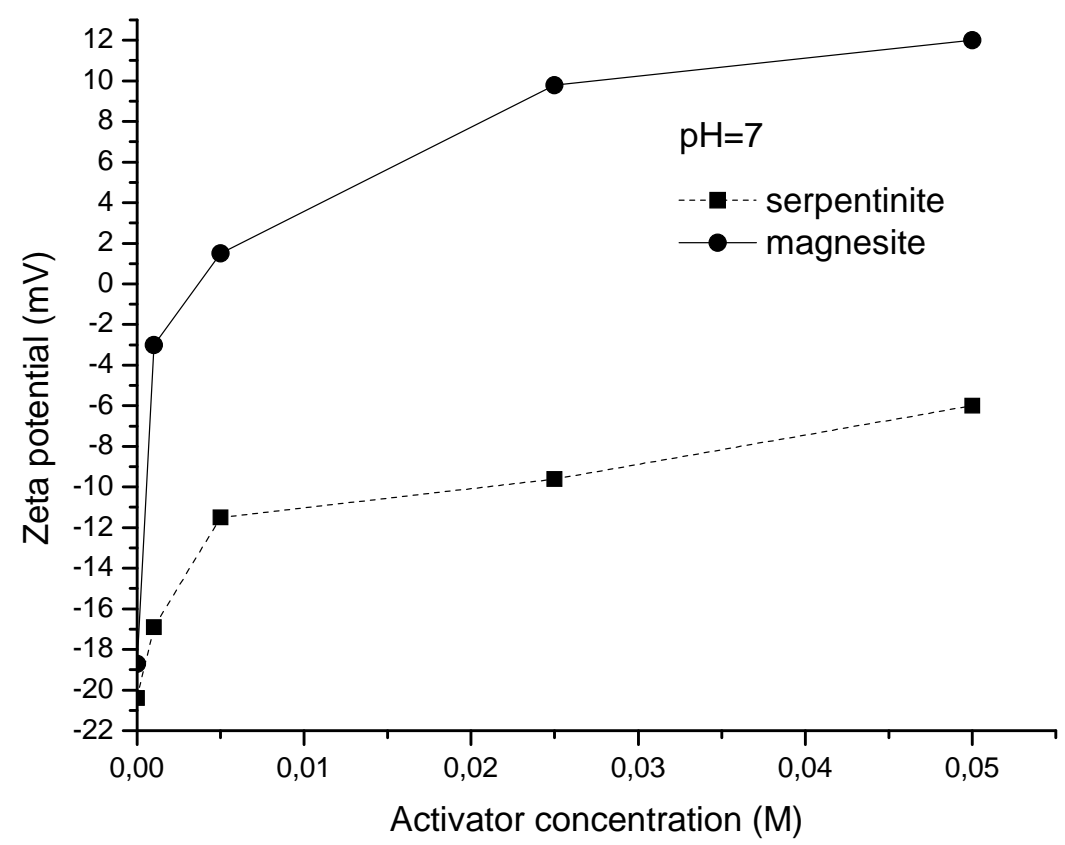

Fig. 3 Zeta potential changes of activated magnesite and serpentinite as a function of nickel ion concentration.

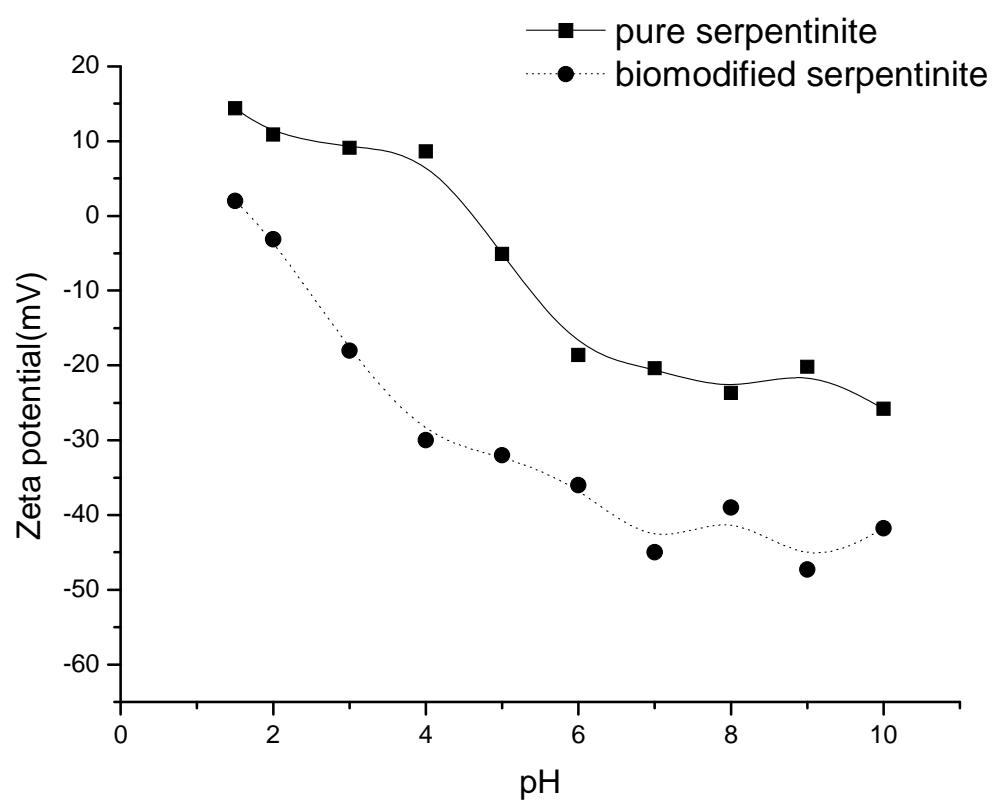

Fig. 4 Zeta potential changes of serpentinite as a function of time.

This trend is similar to the electrokinetic behaviour of kaolinite with mono-valent cations such as $\mathrm{Li}^{+}$and $\mathrm{Na}^{+}$ and double-valent cations such as $\mathrm{Ca}^{2+}$ and $\mathrm{Mg}^{2+}[20]$.

The effect of biosurfactant conditioning on the zeta potential of serpentinite is presented in Fig. 4. A shift of $\mathrm{pH}_{\text {iep }}$ values from $\mathrm{Ph}=4.5$ to $\mathrm{pH}=2.0$ was observed.
These results appear to show that this biosurfactant is negatively charged and readily adsorbed onto the serpentinite surface, resulting in zeta potential changed. Consequently, the adsorption of biosurfactant onto the magnesite surface caused an increase of negative values of zeta potential. Fig. 5 presents the changes of zeta potential of magnesite particles before and after 
biomodification process.

The amounts of $\mathrm{Ni}(\mathrm{II})$ ions adsorbed to serpentinite and magnesite particles are presented in Fig. 6. These results correspond with the zeta potentials of silicate minerals activated by $\mathrm{Cu}(\mathrm{II})$ and $\mathrm{Ni}(\mathrm{II})$ ions [21].

The flotability of serpentinite and magnesite as the concentration function of typical anionic collector like SDS (sodium dodecylosulphonate) at the $\mathrm{pH}$ range of $7.7-8.4$ is presented in Fig. 7. Good flotability is observed for pure minerals and also for minerals whose surface was treated by $\mathrm{Ni}(\mathrm{II})$ ions solution (activated surface). Practically, no separation conditions for these two minerals were observed. The improve conditions for selective separation between serpentinite and magnesite was observed in the flotation experiments carried out with both minerals, when the fermentation broth with biosurfactant was used as collector reagent. The recovery after $30 \mathrm{~min}$ flotation for activated magnesite was up to $50 \%$, while the recovery of activated serpentinite was only $35 \%$. Better flotation

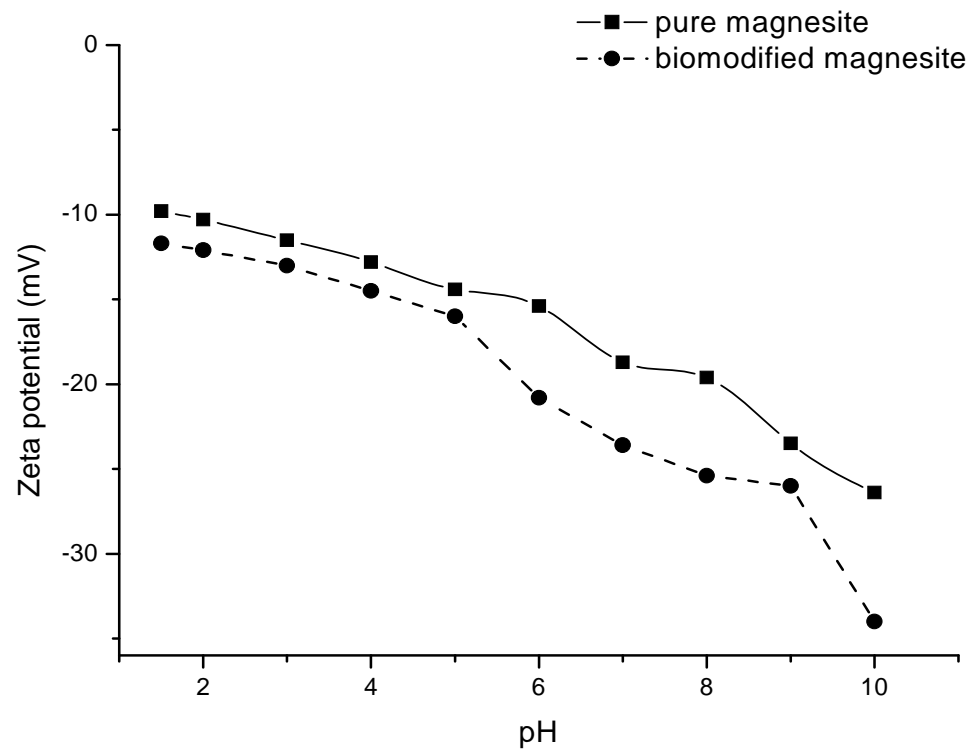

Fig. 5 Zeta potential changes of magnesite as a function of time.

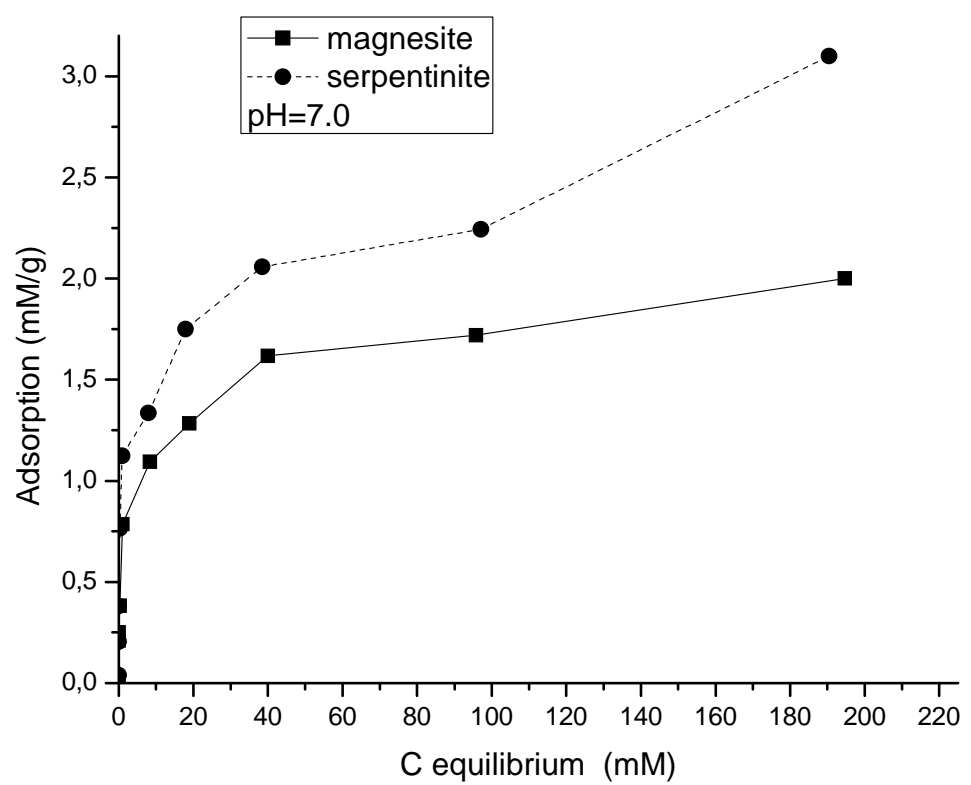

Fig. 6 Isotherms of nickel ion adsorption onto magnesite and serpentinite surface. 

Serpentinite Using Biosurfactants and Surfactants

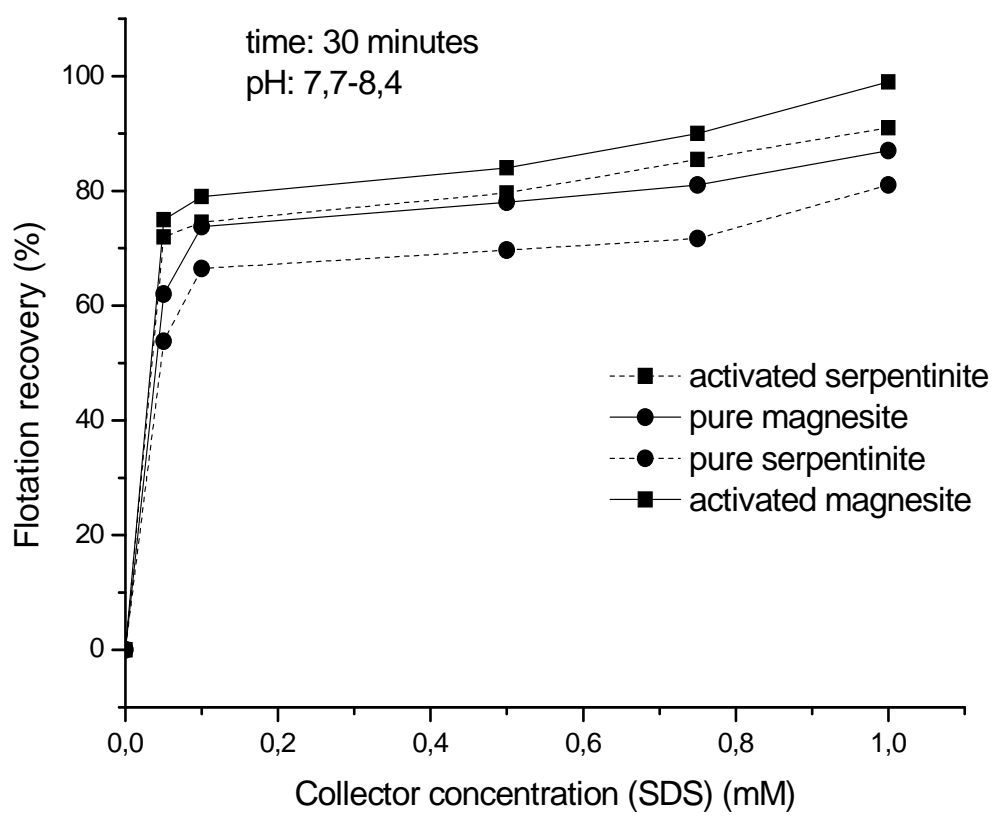

Fig.7 Magnesite and serpentenite flotation as a function of collector concentration (SDS).

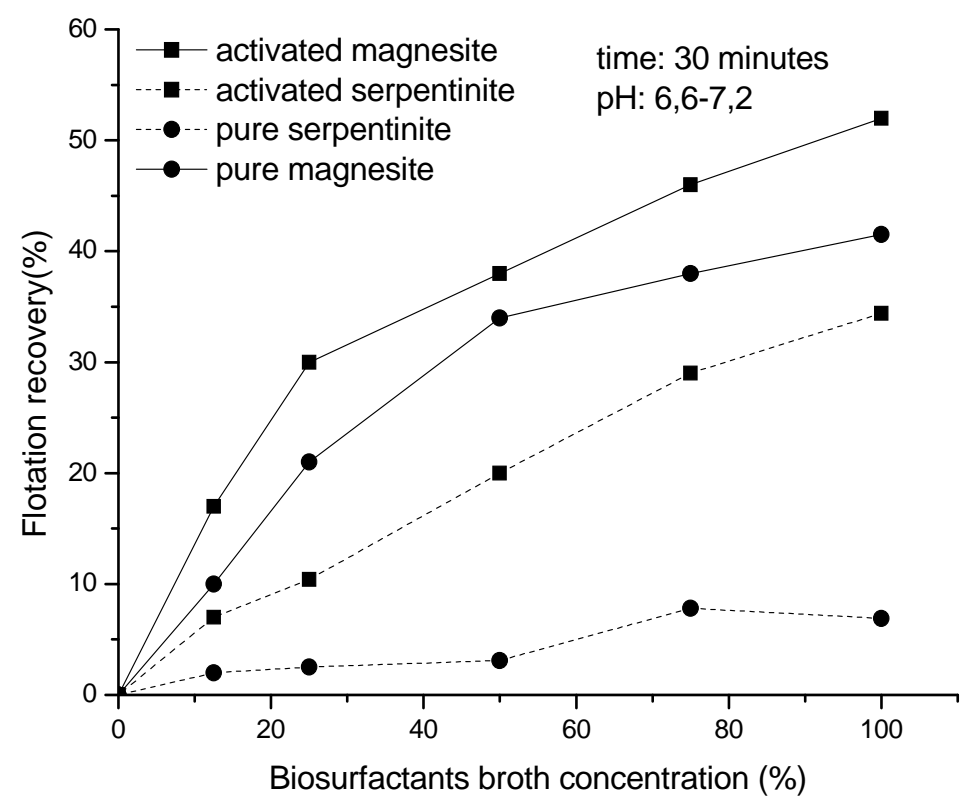

Fig. 8 Magnesite and serpentenite bioflotation as a function of collector concentration (biosurfactants).

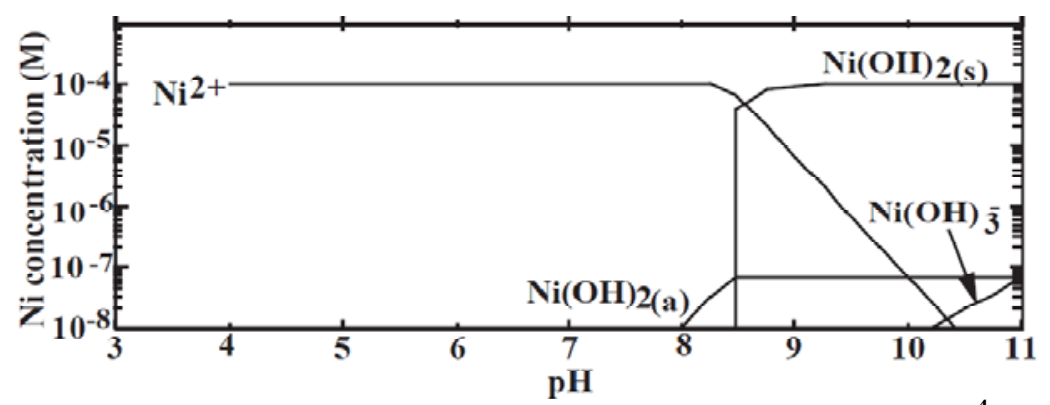

Fig. 9 Calculated concentration of nickel species in solution (thermodynamic calculations with $10^{-4} \mathrm{M} \mathrm{Ni(II)} \mathrm{as} \mathrm{a} \mathrm{function} \mathrm{of} \mathrm{pH.}$ 
conditions were for pure minerals. The recovery for magnesite was $40 \%$ but for magnesite the recovery was only 5\% (Fig. 8). These results demonstrate the potential of separation of magnesite and serpentinite using fermentation broth with biosurfactant as a collector at neutral $\mathrm{pH}$. The separation of these two minerals is also possible when the surfaces of minerals were activated by $\mathrm{Ni}(\mathrm{II})$ ions.

\section{Conclusions}

The zeta potentials of serpentinite and magnesite before and after the surface activation by nickel ions were measured. The adsorption of nickel ions caused the mineral surfaces to become more positively charged. The adsorption of biosurfactant causes an increase in the negative value of zeta potential This adsorption changes the value of isoelectric point for serpentinite from $\mathrm{pH}=4.5$ to $\mathrm{pH}=2.0$. The flotation studies showed the differences between flotability of serpentinite and magnesite when the fermentation broth containing biosurfactan was used as a collector. These differences remained after the activation of mineral surface by nickel ions.

\section{Acknowledgements}

This paper is co-financed by the European Union as a part of the European Social Fund.

\section{References}

[1] Hanumantha Rao,K.,Vilinska, A., and Chernyshova, I.V. 2010. "Minerals Bioprocessing: R \& D Needs in Mineral Biobeneficiation.”Hydrometallurgy 104: 465-470.

[2] Zheng, X., Arps, P.J., and Smith, R.W. 2001. “Adhesion of Two Bacteria onto Dolomite and Apatite; Their Effect on dolomite Depression in Anionic."Int. J. Miner. Process. 62: 159-172.

[3] Pecina, E.T., Rodroguez, M., Castillo, P., Diaz, V., and Orrantia, E. 2009. "Effect of LeptospirillumFerrooxidans on Flotation Kinetics of Sulphide Ores."Minerals Engineering22: 462-8.

[4] Rodriguez, M., Castillo, P., Diaz, V., and Orrantia, E.2009. "Effect of LeptospirillumFerrooxidanson the Flotation Kinetics of Sulphide Ores."Minerals Engineering22: 462-8.
[5] Mehrabani, J.V., Noaparast, M., Mousavi, M.S., Dehghan, R., Rasooli, E., and Hajizadeh, H. 2010. "Depression of Pyrite in the Flotation of High Pyrite Low-Grade Lead-Zinc Ore Using AcidithiobacillusFerooxidans.”Minerals Engineering 23: 10-6.

[6] Vilinska, and Hanumantha Rao, K. 2008. "LeptosririllumFerrooxidans - Sulfide Mineral Interaction with Reference to Bioflotation and Bioflocculation.”Trans. Nonferrous Met. Soc. China 18: 1403-9.

[7] Patra, P., and Natrajan, K.A. 2008. "Role of Mineral Specific Bacterial Proteins in Selective Flocculation and Flotation.”Int. J. Miner. Process. 88: 53-8.

[8] Fornasiero, D., and Ralston, J.2005.“Cu(II) and Ni(II) Activation in the Flotation of Quartz, Lizardite and Chlorite.”Int. J. Miner. Process. 76: 75-81.

[9] deMesquita, L.M.S., Lins, F.F., and Terem, L.M. 2003. "Interaction of a Hydrophobic Bacterium Strain in a Hematite-Quartz Flotation System.”Int. J. Miner. Process. 71: 31-44.

[10] Botero Casas, A.E.,Torem, L.M., and de Mesquita,L.M.S. 2008. "Surface Chemistry Fundamentals of Biosorption of RhodococcusOpacus and Its Effect in Calcite and Magnesite Flotation."Minerals Engineering21: 83-92.

[11] Sabari Prakasan, M.R., and Natrajan, K.A. 2010. "Microbial Induced Separation of Quartz from Hematite Using Sulfate Reducing Bacteria.”Colloids Surfaces B: Biointerfaces 78: 163-170.

[12] Banat, I.M. 1995. "BiosurfactantsProduction and Possible Uses in Microbial Enhanced Oil Recovery and Oil Pollution Remediation: A Review."Bioresources Technology51: 1-12.

[13] Wang, S., and Mulligan, C.N. 2009. "RhamnolipidBiosurfactant-Enhanced Soil Flashing for the Removal of Arsenic and Heavy Metals from Mine Tailings."Process Biochemistry 44: 296-301.

[14] Park,A.A-H.Jadhav, R., and Fan, L-S. 2003. “ $\mathrm{CO}_{2}$ Mineral Sequestration: Chemical Enhanced Aqueous Carbonation of Serpentine.”Canadian J. Chemical Eng. 81: 885-890.

[15] Tair, S., Eloneva, S., Fogelholm, C-J., and Zevenhoven, R. 2009. "Fixation of Carbon Dioxide by Producing Hydromagnesite from Serpentinite.”Applied Energy 86: 214-8.

[16] Krevor, S.C.M., and Lackner, K.S. 2011. “Enhancing Serpentine Dissolution Kinetics for Mineral Carbon Dioxide Sequestration.”International J. Greenhouse Ges Control 5: 1073-1080.

[17] Kosaric, N. 1992. “Biosurfactants in Industry.”Pure \& Appl. Chem. 64 (11): 1731-7.

[18] Oskierski, H.C., Dlugogorski, B.Z., and Jacobsen, G. 2013. "Sequestration of Atmospheric $\mathrm{CO}_{2}$ in Weathering-Derived Serpentinite-Hosted 

Serpentinite Using Biosurfactants and Surfactants

MagnesiteDoposite. ${ }^{14} \mathrm{C}$ Tracing of Carbon Sources and Age Constraints for a Refined Genetic Model."GeochmicaetCosmochimicaActa 122: 226-246.

[19] Caillaud, J., Proust, D., Philippe, S., Fountaine, C., and Fialin, M. 2009. "Trace Metals Distribution a SerpentiniteWeathering at the Scales of the Weathering Profile and Its Related Weathering Microsystems and Clay Minerals.”Geoderma147: 199-208.
[20] Yukselen, Y., and Kaya, A. 2003. "Zeta Potential of Kaolinite in the Presence of Alkali, Alkaline Earth and HydrolysableMetal Ions.”Water, Air, and Soil Pollution 145: 155-168.

[21] Patra, P., and Natarajan, K.A. 2003. "Microbially-Induced Flocculation and Flotation for Pyrite Separation from Oxide Gangue Minerals.”Minerals Engineering 16: 965-973. 